\title{
Response surface optimization for development of Dragon fruit based ready to serve drink
}

\author{
Kirti Jalgaonkar, Manoj Kumar Mahawar*, Sakharam Kale, Prerna Nath Kale, Bhushan \\ Bibwe, Ajinath Dukare, Pankaj Kannaujia and Vijay Singh Meena
}

Horticultural Crop Processing Division, ICAR- Central Institute of Post- Harvest Engineering and Technology, Abohar -152116 (Punjab), INDIA

*Corresponding author. E-mail: manojmahawar362@gmail.com

Received: September 18, 2017; Revised received: October 25, 2017; Accepted: February 2, 2018

\begin{abstract}
Dragon fruit based ready to serve drink (RTS) was formulated using dragon fruit (60-80\% v/v), grape juice $(0-10 \% \mathrm{v} / \mathrm{v})$ and sugar syrup $(2-6 \% \mathrm{v} / \mathrm{v})$. The juice concentrations were optimized using response surface methodology (RSM) following box-behnken design (BBD) for obtaining blended RTS drink with higher functional and nutritional characteristics like total soluble solid (TSS), titratable acidity, ascorbic acid content, total phenol content, colour and sensory evaluation. Results showed that there was significant $(P<0.01)$ effect of incorporating grape juice and sugar syrup which further improved the organoleptic properties of the blended RTS.Optimum juice percentages obtained for the best blend formulation were,dragon fruit (70\%), grape juice $(5 \%)$ and sugar syrup (3\%), respectively. The beverage was observed to be acceptable in terms of its nutritional value and overall acceptability.
\end{abstract}

Keywords: Blended RTS, Dragon fruit, Grape juice, Response surface methodology

\section{INTRODUCTION}

Dragon fruit (Hylocereus) is a non-climacteric fruit belongs to one of the cactus species. It is also known as Pitaya and it is dark red to pink in colour with green overlapping on the surface. There are three most common varieties of the dragon fruit; Hylocereus Undatus (red skin fruit with white flesh), Hylocereus costaricensis (red skin fruit with red flesh) and Hylocereus megalanthus (yellow skinned fruit with white flesh) (Dailami, 2009). It is well recognized as an ornamental plant, as blooming large scented flowers and nowadays it is also spreading worldwide for its fruits. Thought it is the native fruit of Mexico, Central and South America, due to its impressive flavour, nutritional value and other features, dragon fruit has gained attention among researchers mostly in Asian countries as well (Hoa 2006; Harivaindaran et al., 2008; Suguna et al., 2011). The fruit, having high antioxidant activity is the rich source of potassium, serum protein, fibre, vitamins and minerals which are major needs of human diet (Le Bellec et al., 2006, Davis 2007). Additionally, due to the presence of betacyanin, fruit shell has great potential to be used as a natural pigment (Kim et al., 2011).

The most valuable and commonly used edible part of dragon fruit is the fruit flesh which constitutes $70-80 \%$ $(\mathrm{w} / \mathrm{w})$ of the fruit, sweet and white in colour having numerous black seeds that can be consumed with the flesh. Flesh is firm and crispy in texture, with lingering
flavour.The fruit is consumed as a flesh or in the form of juice, jellies, marmalades, jam, wine and beverages (Wybraniec and Mizrahi, 2002; Chuah et al., 2008).The dragon fruit juice is popularly enjoyed as a healthy refreshing drink. Consumption of the juice has health benefits and contributes to lower the blood cholesterol level and to neutralize the toxic elements in the blood, it improves the blood circulation of body (Chen et al., 2006). It also helps to prevent colon cancer, diabetes, control sugar level and promote dental health (Anonymous 2017). Considering the functional importance, nowadays this fruit has gained significant economic value in the market (Kim et al., 2011). Keeping in view of the above facts, the present study was therefore formulated to prepare a functional health drink using dragon fruit juice with an optimal blend of grape juice and pomegranate juice. This will improve the overall utilization and value addition aspects of dragon fruit.

\section{MATERIALS AND METHODS}

Raw materials: Fresh dragon fruits, pomegranate and black grapes were procured from the local market of Abohar (Punjab), India. The fruits were then washed thoroughly for the removal of dust etc. before processing for juice.

Preparation of fruit juices: Dragon fruit was cut into two halves, and pulp was removed from the fruit shell. This pulp was homogenized, and juice was extracted 
by filtering it through a muslin cloth. Pomegranate skin and pericarp was removed, and arils were separated. Arils were crushed, and juice was extracted by filtering it through a muslin cloth. Black grapes were crushed for the extraction of juice. Extracted juices were heated individually at $85 \pm 2{ }^{\circ} \mathrm{C}$ for 3 minutes and then centrifuged at $7000 \mathrm{rpm}$ for 10 minutes to remove some undesirable material present if any. Pure juice was filled in the glass bottles and pasteurized at $85 \pm 2^{\circ}$ $\mathrm{C}$ for 15 minutes to kill the spoilage forming bacteria. These juices were then stored in the cold chamber maintained at $4^{\circ} \mathrm{C}$ till further use.

Preparation of sugar syrup: For the preparation of sugar syrup $100 \mathrm{~g}$ of sugar was dissolved in $100 \mathrm{ml}$ of water and placed over the hot plate $\left(90^{\circ} \mathrm{C}\right)$ to prepare a homogenous mixture.Pomegranate juice was used as a supplement for making up the resultant volume to $100 \%$ and its concentration got varied for each experimental run based on the amount of other three juice used.

Experimental design: Response surface methodology was used for the experimental design and optimization of the juice constituents to achieve the best possible combination of RTS. Experiments were laid down using three independent variables with their respective three levels, i.e. dragon juice $(60-80 \%)$, grape juice $(0$ $10 \%$ ) and sugar syrup (2-6\%) using box-behnken design. The concentration of selected process variables was decided on the basis of a review of the literature and preliminary trials. The coded and actual level of the variables along with 17 experimental runs is presented in Table 1. The effect of these independent variables was evaluated on selected process responses, i.e. total soluble solids ( ${ }^{\circ}$ Brix $), \mathrm{pH}$, titratable acidity $(\%)$, ascorbic acid (mg/100g), total phenol content $(\mathrm{mg} / 100 \mathrm{~g})$ and sensory evaluation which include taste, color, flavor, overall acceptability.

Statistical analysis: Data analysis using regression coefficients $(\beta)$ was accomplished using Design expert software 9.0 (Stat-Ease Inc., Minneapolis, USA). A quadratic polynomial regression model was assumed for predicting the response variable $(\mathrm{Y})$ and the data were fitted in the form of second order polynomial equation as equation 1 .

$$
Y=\beta_{0}+\sum_{i=1}^{n} \beta_{i} X_{i}+\sum_{i=1}^{n} \sum_{j=i+1}^{n} \beta_{\ddot{y}} X_{i} X_{j}+\sum_{i=1}^{n} \beta_{\ddot{u}} X_{i}^{2}
$$

Where, $\mathrm{Xi}, \mathrm{Xj}$ are independent variables which influence the response Y (dependent variable) and ' $\mathrm{n}$ ' is a number of dependent variables. $\beta_{o}, \beta_{i}$ and $\beta_{i j}$ are the regression coefficients to be determined. The adequacy of the model was determined using model analysis, lack-of-fit test and coefficient of determination $\left(\mathrm{R}^{2}\right)$ values. $R^{2}$ value represents the proportion of variability in the data accounted for by the model. Response sur- face plots were also generated using RSM to substantiate the graphical representation of experimental data further.

pH and total soluble solids (TSS): $\mathrm{pH}$ of the RTS was measured using digital $\mathrm{pH}$ meter (Make: EUTECH, range: 0 to 14 , resolution $0.01 \mathrm{pH}$ ), whereas total soluble solids were measured using digital refractometer (Make: ATAGO, range: 0 to $93 \%$ brix).

Titratable acidity (TA) and ascorbic acid (AA): AOAC (2000) methods were employed for analysis of titratable acidity (TA) (Method 942.15), ascorbic acid (AA) (Method 967.21).

Colour: Colour of developed RTS was measured using Hunter colorimeter D25 optical sensor (Hunter Associates Laboratory, Trestoa, VA, USA) in terms $\mathrm{L}^{*}, \mathrm{a}^{*}$ and $\mathrm{b}^{*}$ values

Total phenol content (TPC): $5 \mathrm{ml}$ juice was dissolved in $20 \mathrm{ml}$ of $80 \%$ ethanol and centrifuged. Then $0.1 \mathrm{ml}$ of aliquot was taken and the volume was made up to 3 $\mathrm{ml}$ with water. $0.5 \mathrm{ml}$ of Folin-Ciocalteu reagent (FCR) was added into the sample and after 10 minutes, $2 \mathrm{ml}$ of $20 \%$ sodium carbonate solution was added. Sample was mixed thoroughly and tubes were placed in a dark place for exactly 30 minutes. Total phenolic was determined calorimetrically at $750 \mathrm{~nm}$ against reagent blank.

Sensory evaluation: Sensory evaluation of developed RTS drink was carried out as per BIS method [BIS: 6273-(1971)] using 9 point hedonic scale.

Optimization: Optimum values of the processing variables by which best quality end product can be obtained were worked out with numerical optimization technique of multiple responses using RSM. This process requires assigning goals i.e. maximum, minimum and keeping in range for process variables and responses. Optimal solution having maximum desirability has been selected and experiments were carried out on those conditions to reassure those values.

Table 1. Experimental design with actual and coded values (in parenthesis).

\begin{tabular}{llll}
\hline $\begin{array}{l}\text { Experi- } \\
\text { mental run }\end{array}$ & $\begin{array}{l}\text { Dragon } \\
\text { juice, } \mathbf{X}_{\mathbf{1}}, \mathbf{( \% )}\end{array}$ & $\begin{array}{l}\text { Grape juice, } \\
\mathbf{X}_{\mathbf{2}}, \mathbf{( \% )}\end{array}$ & $\begin{array}{l}\text { Sugar } \\
\text { up, } \mathbf{X}_{\mathbf{3}}, \mathbf{( \% )}\end{array}$ \\
\hline 1 & $70(0)$ & $5(0)$ & $4(0)$ \\
2 & $80(1)$ & $0(-1)$ & $4(0)$ \\
3 & $60(-1)$ & $5(0)$ & $2(-1)$ \\
4 & $70(0)$ & $5(0)$ & $4(0)$ \\
5 & $70(0)$ & $5(0)$ & $4(0)$ \\
6 & $70(0)$ & $0(-1)$ & $6(1)$ \\
7 & $80(1)$ & $5(0)$ & $2(-1)$ \\
8 & $60(-1)$ & $5(0)$ & $6(1)$ \\
9 & $70(0)$ & $0(-1)$ & $2(-1)$ \\
10 & $80(1)$ & $5(0)$ & $6(1)$ \\
11 & $80(1)$ & $10(1)$ & $4(0)$ \\
12 & $70(0)$ & $10(1)$ & $6(1)$ \\
13 & $60(-1)$ & $10(1)$ & $4(0)$ \\
14 & $60(-1)$ & $0(-1)$ & $4(0)$ \\
15 & $70(0)$ & $10(1)$ & $2(-1)$ \\
16 & $70(0)$ & $5(0)$ & $4(0)$ \\
17 & $70(0)$ & $5(0)$ & $4(0)$ \\
\hline
\end{tabular}




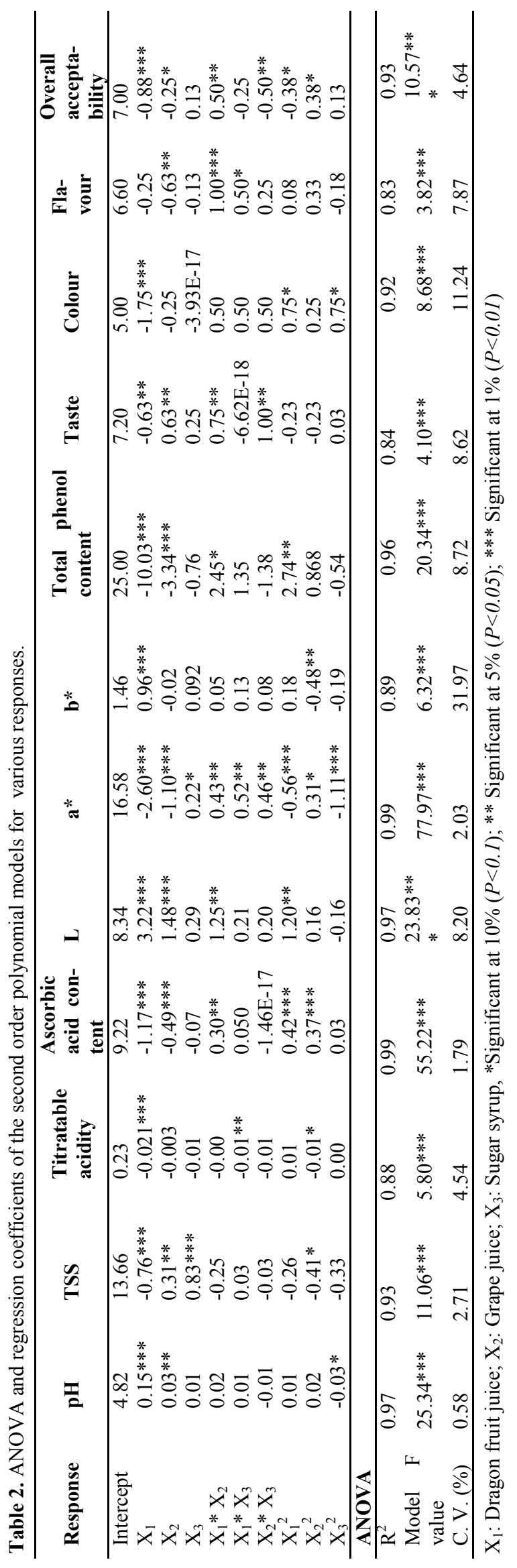

Table 3. Comparison of experimental values with predicted values.

\begin{tabular}{lll}
\hline Response & $\begin{array}{l}\text { Predicted } \\
\text { value } \pm \text { SD }\end{array}$ & $\begin{array}{l}\text { Actual value } \pm \\
\text { SD }\end{array}$ \\
\hline $\mathrm{pH}$ & $4.67 \pm 0.32$ & $4.67 \pm 0.2$ \\
$\mathrm{TSS}$ & $13.07 \pm 1.65$ & $11.90 \pm 0.98$ \\
$\mathrm{TA}$ & $0.24 \pm 0.05$ & $0.22 \pm 0.03$ \\
$\mathrm{AA}$ & $11.99 \pm 2.04$ & $8.37 \pm 1.84$ \\
$\mathrm{~L}^{*}$ & $6.26 \pm 0.50$ & $7.74 \pm 0.87$ \\
$\mathrm{a}^{*}$ & $20.53 \pm 2.54$ & $19.29 \pm 1.36$ \\
$\mathrm{~b}^{*}$ & $0.29 \pm 0.07$ & $1.86 \pm 0.6$ \\
$\mathrm{TPC}$ & $44.51 \pm 4.25$ & $43.80 \pm 5.07$ \\
Taste & $7.61 \pm 0.74$ & $8.60 \pm 0.93$ \\
Colour & $8.66 \pm 1.12$ & $8.00 \pm 1.25$ \\
Flavour & $9.00 \pm 0.96$ & $8.50 \pm 0.82$ \\
Overall acceptability & $8.50 \pm 0.56$ & $8.50 \pm 0.74$ \\
\hline
\end{tabular}

Values are represented as Average \pm Standard deviation

\section{RESULTS AND DISCUSSION}

Estimated regression coefficients of the second order polynomial models for all the responses and their statistical validity defining values are reported in Table 2 . Regression models for $\mathrm{pH}$, TSS, titratable acidity, ascorbic acid, $L^{*}, a^{*}, b^{*}$, total phenol content and sensory evaluation were highly significant $(P \leq 0.01)$ with high coefficient of determination $\left(\mathrm{R}^{2} \geq 0.83\right)$.

Furthermore, $\mathrm{F}$ value reflected that all the models $(\mathrm{pH}$, TSS, titratable acidity, ascorbic acid, colour, total phenol content and sensory evaluation) were significant. Coefficient of variation (CV) was found less than $10 \%$ (except for 'colour') which established that the experiments were having reasonable accuracy and the models could be reproducible. It signifies that the model coefficients represent the responses in a suitable manner and simultaneously they can be used to predict the values of dependent parameters within the mentioned range of process variables. Also, the p-values were used as a tool to check the significance of each of the coefficients, which in turn indicate the pattern of interactions between the variables. The insignificant terms from full second order polynomial equation were excluded to get the best-fitted simple predictive equation (Mahawar et al., 2016, Bibwe et al., 2017).

pH: The predicted model indicated (Table 2) that the linear effect of dragon fruit juice $(P<0.01)$, grape juice $(P<0.05)$ and quadratic effect of sugar syrup $(P<0.1)$ were the determining factors for $\mathrm{pH}$ of the RTS. Response surface plot (Fig 1) showed that highest value of $\mathrm{pH}$ (5.04) was recorded at the combination of $80 \%$ dragon fruit juice, $10 \%$ grape juice and $4 \%$ sugar syrup. Whereas, lowest $\mathrm{pH}(4.65)$ was recorded at $60 \%$ dragon fruit juice, $4 \%$ sugar syrup with no added grape juice. This variation in $\mathrm{pH}$ might be due to the high acidity of dragon fruit juice and grape juice. The multiple regression analysis resulted the following prediction equation:

$\mathrm{pH}=4.82+0.15 \mathrm{X}_{1}+0.03 \mathrm{X}_{2}-0.03 \mathrm{X}_{3}^{2}$ 


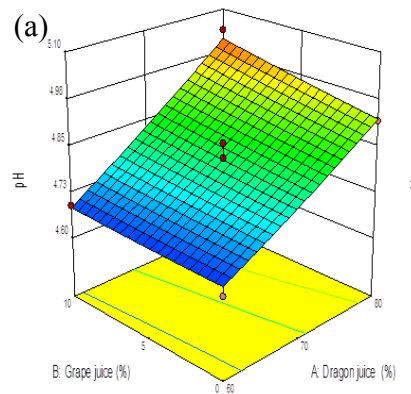

(b)

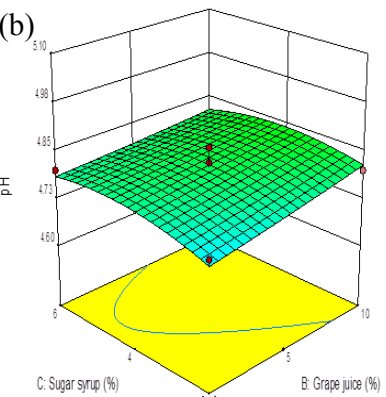

Fig. 1. Response surface plots for $p H$ as a function of (a) grape juice and dragon juice (b) sugar syrup and grape juice (a)

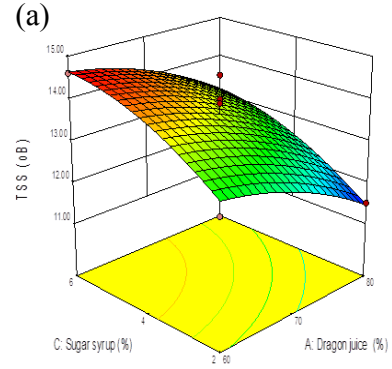

(b)

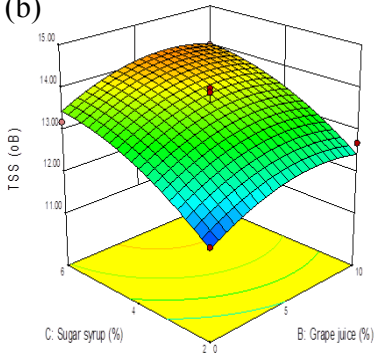

Fig. 2. Response surface plots for TSS as function of (a) sugar syrup and dragon juice (b) sugar syrup and grape juice

TSS: It was revealed from the quadratic model fitted (Table 2) for the experimental data that all the three process variables, i.e. dragon fruit juice $(P<0.01)$, grape juice $(P<0.05)$ and sugar syrup $(P<0.01)$ significantly affected the final TSS of dragon fruit based RTS. It was observed that TSS was positively correlated with grape juice concentration and sugar syrup; however negative correlation was observed with dragon fruit concentration (Fig 2). Higher coefficient of determination value $\left(\mathrm{R}^{2}=0.93\right)$ suggested that the model represented the relationships among the selected process variables in a correct manner. The lowest and highest TSS was 11.50 and 14.60, respectively. The regression equation obtained was as follows:

$\mathrm{TSS}=13.66-0.76 \mathrm{X}_{1}+0.31 \mathrm{X}_{2}+0.83 \mathrm{X}_{3}-0.41 \mathrm{X}_{2}^{2}$ $0.33 \mathrm{X}_{3}^{2}$

Titratable acidity (TA): It was observed from the coefficient table (Table 2) that dragon fruit juice concentration had a significant negative effect $(P<0.01)$ on TA of developed RTS. Also, the interaction effect of dragon fruit juice and sugar syrup $(P<0.05)$ and the quadratic effect of grape juice $(P<0.1)$ have their significant negative effect on TA. Response surface plot (Fig 3) confirms the decrease in TA of RTS with an increase in dragon fruit juice concentration. The highest TA $(0.26)$ was recorded at $60 \%$ dragon fruit juice and $5 \%$ grape juice concentration, while it was reduced to 0.19 at $80 \%$ dragon fruit juice and $5 \%$ grape juice. The second order polynomial equation can be written as follows:
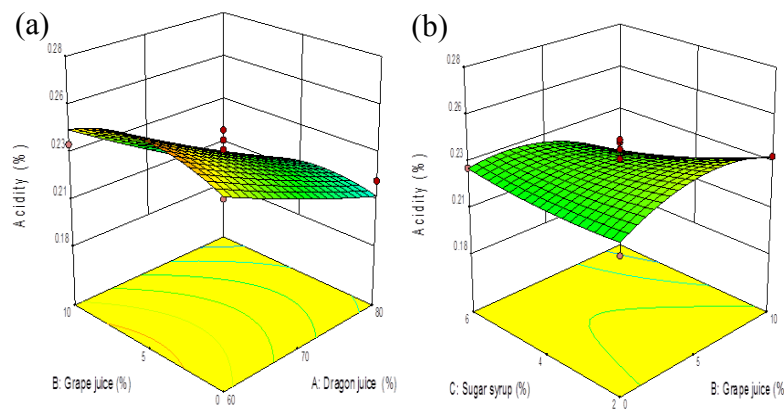

Fig. 3. Response surface plots for titratable acidity as a function of (a) grape juice and dragon juice (b) sugar syrup and grape juice
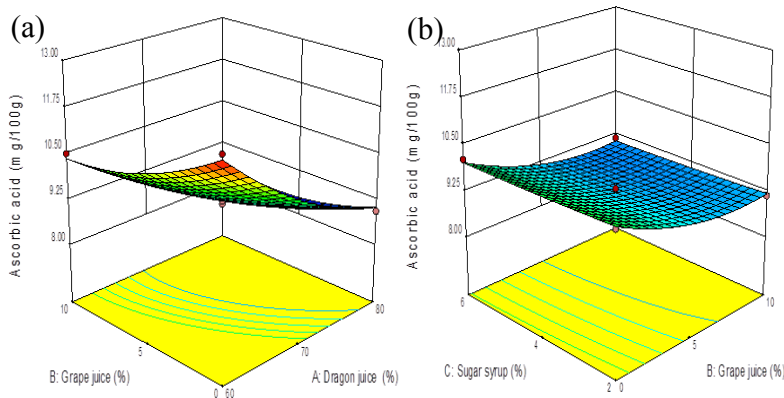

Fig. 4. Response surface plots for ascorbic content as a function of (a) sugar syrup and dragon juice (b) sugar syrup and grape juice.

$\mathrm{TA}=0.23-0.021 \mathrm{X}_{1}-0.01 \mathrm{X}_{1} \mathrm{X}_{3}-0.01 \mathrm{X}_{2}^{2}$

Ascorbic acid (AA) content: Regression table (Table 2) showed that AA content of the RTS was reduced significantly $(P<0.01)$ with the linear increase of dragon fruit juice and grape juice concentration. Sugar syrup concentration had no significant effect on the ascorbic acid content. Interaction effect of dragon fruit juice and grape juice had positive effect $(P<0.05)$, while the quadratic effects of dragon juice and grape juice were also found significantly $(P<0.01)$ affecting AA content of developed RTS. Highest ascorbic acid recorded was $12.10 \mathrm{mg} / 100 \mathrm{~g}$ of the combination of $80 \%$ dragon fruit juice, 5\% grape juice and 6\% sugar syrup, whereas lowest ascorbic acid content $(8.53 \mathrm{mg} / 100 \mathrm{~g})$ was observed at the combination of $70 \%$ dragon fruit juice, $5 \%$ grape juice and $4 \%$ sugar syrup, respectively. The $\mathrm{R}^{2}$ value was also found to be on the higher side, i.e. 0.98. Graphical representation of the process variables with AA content has been shown in Fig 4. The empirical relationship between AA content and the independent variables is denoted by the following equation:

$\mathrm{AA}=9.22-1.17 \mathrm{X}_{1}-0.49 \mathrm{X}_{2}+0.30 \mathrm{X}_{1} \mathrm{X}_{2}+0.42$ $\mathrm{X}_{1}^{2}+0.37 \mathrm{X}_{2}^{2}$

Colour: Among the various quality attributes as appreciated by consumers, colour has been recognized as influencing consumer acceptance (Melendez-Martinez et al., 2004). It was measured in terms of $\mathrm{L}^{*}$, $\mathrm{a}^{*}$ and $b^{*}$. The lightness, $L^{*}$, represents the darkest black at $\mathrm{L}^{*}=0$, and the brightest white at $\mathrm{L}^{*}=100$. The red/ green opponent colors are represented along the $\mathrm{a}^{*}$ 

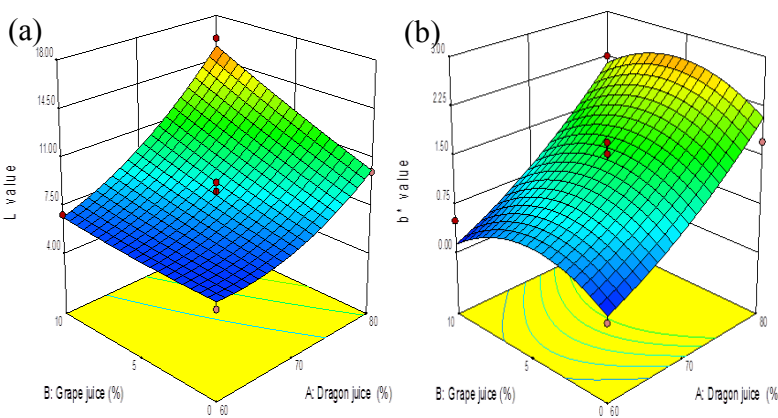

Fig. 5. Response surface plots of (a) $L$ value and (b) $b^{*}$ value as a function dragon juice and grape juice.
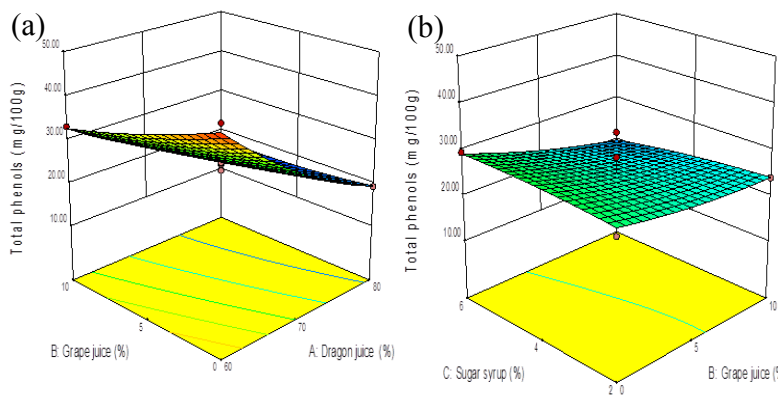

Fig. 6. Response surface plots for TPC as a function of (a) grape juice and dragon juice (b) sugar syrup and grape juice

axis, with green at negative $a^{*}$ values and red at positive $\mathrm{a}^{*}$ values. The yellow/blue opponent colors are represented along the $b^{*}$ axis, with blue at negative $b^{*}$ values and yellow at positive $b^{*}$ values.

$L^{*}$ value: Among the three process variables, dragon fruit juice and grape juice have played an important role on $\mathrm{L}^{*}$ value of dragon based RTS. Both dragon juice and grape juice had significant positive effect $(P<0.01)$ on lightness of the RTS (Table 2$)$. The interaction effect of dragon juice and grape juice $(P<0.05)$ and the quadratic effect of dragon juice $(P<0.05)$ had their profound effect on $\mathrm{L}^{*}$ value. Lowest lightness value (5.69) was recorded at 70\% dragon fruit juice, $5 \%$ grape juice and 4\% sugar syrup; which highest value (16.20) was observed at $80 \%$ dragon fruit juice with $0 \%$ grape juice and $4 \%$ sugar syrup. Increase in $\mathrm{L}$ value was may be because of the increased dragon juice concentration and reduced grape juice concentration in the RTS. The data trend has been shown in Fig 5 (a). The following regression equation showed the relationship of $\mathrm{L}^{*}$ value and the process variables:

$\mathrm{L}^{*}$ value $=8.34+3.22 \mathrm{X}_{1}+1.48 \mathrm{X}_{2}+1.25 \mathrm{X}_{1} \mathrm{X}_{2}+$ $1.20 \mathrm{X}_{1}^{2}$

$a^{*}$ value: Table 2 showed that most of the linear, interaction and quadratic effects of all the process variables had their significant effect on $a^{*}$ value. Both dragon juice and grape juice were negatively correlated $(P<0.01)$ with a* value of developed RTS, while sugar syrup was positively associated $(P<0.1)$ with a* value. All the interaction effects, i.e. (dragon juice $\times$ grape juice), (grape juice $\times$ sugar syrup) and (dragon juice $\times$
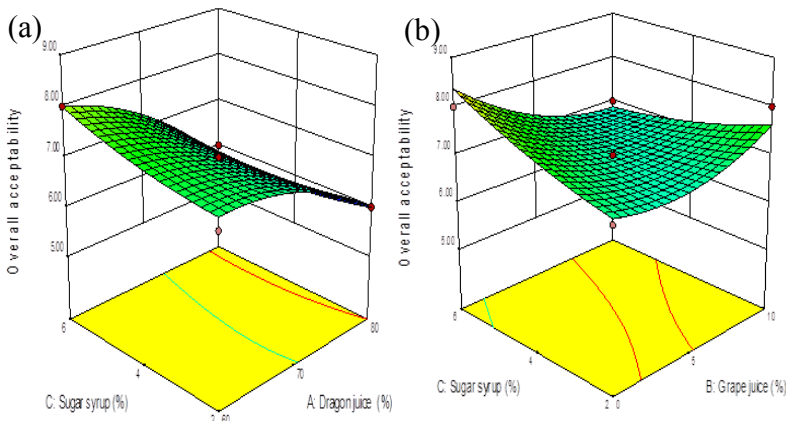

Fig. 7. Response surface plots for overall acceptability as function of (a) sugar syrup and dragon juice (b) sugar syrup and grape juice

sugar syrup) had their significant positive effect $(P<0.05)$ on a* value of developed RTS. Also, the quadratic effects of dragon juice and sugar syrup, as well as that of grape juice, had their effects at $1 \%$ and $10 \%$ level of significance, respectively. Lowest $a^{*}$ value (11.49) was recorded at a concentration of $60 \%$ dragon fruit juice, $10 \%$ grape juice and $4 \%$ sugar syrup, whereas, highest (20.52) was recorded at $60 \%$ dragon fruit juice, $5 \%$ grape juice and $6 \%$ sugar syrup, respectively. The data fitted in second-order polynomial equation can be represented by following regression equation:

$\mathrm{a}^{*}$ value $=16.58-2.60 \mathrm{X}_{1}-1.10 \mathrm{X}_{2}+0.22 \mathrm{X}_{3}+0.43$ $\mathrm{X}_{1} \mathrm{X}_{2}+0.52 \mathrm{X}_{1} \mathrm{X}_{3}+0.46 \mathrm{X}_{2} \mathrm{X}_{3}-0.564 \mathrm{X}_{1}^{2}+0.31 \mathrm{X}_{2}^{2}-$ $1.11 \mathrm{X}_{3}^{2}$

b* value: Linear positive effect $(P<0.01)$ of dragon juice concentration can be observed from the regression table (Table 2). $b^{*}$ value got increased from 0.17 at $70 \%$ dragon fruit juice, $10 \%$ grape juice and $2 \%$ sugar syrup concentration to 2.98 at $80 \%$ dragon fruit juice with no added grape juice and $2 \%$ sugar syrup. The positive correlation between dragon juice percentage and $b^{*}$ value can also be seen from Fig 5 (b). The coefficient of determination was also on the higher side, i.e. $\mathrm{R}^{2}=0.89$. The regression equation consisting of the significant terms is as follows:

$\mathrm{b}^{*}$ value $=1.46+0.96 \mathrm{X}_{1}-0.48 \mathrm{X}_{2}^{2}$

Total phenolic content (TPC): The regression coefficients of both dragon fruit juice $(\mathrm{P}<0.01)$ and grape juice concentration $(P<0.01)$ were found to have their negative impact on TPC of developed RTS (Table 2). The highest phenol content $(46.20 \mathrm{mg} / 100 \mathrm{~g})$ was observed at $60 \%$ dragon fruit concentration with $0 \%$ grape juice, which was significantly reduced to 15.90 at $80 \%$ dragon fruit juice and $10 \%$ grape juice. The decrease of phenol content was attributed to the fact that release of phenolics is restricted from the matrix of pectin and polysaccharides due to their adherence with complex cell wall matrices. The lower amount of phenolics in pulp might be another reason for the reduction in TPC of RTS (Siddhuraju et al., 2002). The graphical representation showing the effect of process variables on TPC is given in Fig. 6. The coefficient of 
determination $\mathrm{R}^{2}$ was observed to be 0.96 . The mathematical relationship between TPC and the process variables in coded form can be represented as follows:

$\mathrm{TPC}=25-10.03 \mathrm{X}_{1}-3.34 \mathrm{X}_{2}+2.45 \mathrm{X}_{1} \mathrm{X}_{2}+2.74 \mathrm{X}_{1}^{2}(9)$

\section{Sensory evaluation}

Taste: Taste of the RTS is the most important quality that directly affected on the consumers acceptability. It was observed from sensory evaluation that taste of the RTS varied in a positive manner $(P<0.05)$ with dragon juice concentration, whereas it behaved inversely with grape juice concentration $(P<0.05)$. However, the best sensory score for taste (9) was obtained at $70 \%$ dragon fruit juice, $10 \%$ grape juice and $6 \%$ sugar syrup; no significant difference was obtained when compared with $80 \%$ dragon fruit juice, $5 \%$ grape juice and $6 \%$ sugar syrup. Consequently, when grape juice was not added, the taste score of the RTS was significantly reduced to 5 . Regression model fitted for the taste also indicated that the interaction effects (dragon fruit juice $\times$ grape juice) and (grape juice $\times$ sugar syrup) has a significant positive effect $(P<0.05)$ with higher $\mathrm{R}^{2}$ $(0.84)$. The regression equation containing the significant terms can be depicted as follows:

Taste $=7.20+0.63 \mathrm{X}_{1}-0.63 \mathrm{X}_{2}+0.75 \mathrm{X}_{1} \mathrm{X}_{2}+1.00$ $\mathrm{X}_{2} \mathrm{X}_{3}$

Colour: It was observed that addition of dragon juice concentration has a slightly negative impact $(\mathrm{P}<0.01)$ among the panel members for the acceptability of colour of the RTS but to a certain level. RTS having the highest concentration of dragon fruit juice $(80 \%)$ was least likely and obtained colour acceptability of 4, whereas RTS having a combination of $(60 \%$ dragon fruit juice with no added grape juice and 4\% sugar syrup) was more likely and gained acceptability of 9 . It was revealed from the statistical analysis that grape juice and sugar syrup concentration has no significant effect on the colour acceptability of the RTS. The value for coefficient of determination $\left(\mathrm{R}^{2}\right)$ was 0.92 . The regression equation for colour of RTS in coded form of variables can be written as below:

Colour $=5-1.75 \mathrm{X}_{1}+0.75 \mathrm{X}_{1}^{2}+0.75 \mathrm{X}_{3}^{2}$

Flavour: The predicted response model (Table 2) indicated that there exists negative linear effect of grape juice $(P<0.1)$ and sugar syrup $(P<0.05)$. The interaction effects (dragon juice $\times$ grape juice) and (dragon juice $\times$ sugar syrup) was also found to have effect at $1 \%$ and $10 \%$ level of significance, respectively. Among the three variables, sugar played an important role in flavor of dragon based RTS. It was observed that decrease in sugar content in the blend increased the flavor of prepared RTS. Highest flavour value (9) was recorded at $70 \%$ dragon fruit juice, $10 \%$ grape juice and $2 \%$ sugar syrup; whereas, least value (5) was obtained at $70 \%$ dragon fruit juice, $10 \%$ grape juice and $6 \%$ sugar syrup concentration. The second order polynomial equation can be written as below:

Flavour $=6.60-0.63 \mathrm{X}_{2}+1 \mathrm{X}_{1} \mathrm{X}_{2}+0.50 \mathrm{X}_{1} \mathrm{X}_{3}$
Overall acceptability: It was observed from the sensory evaluation that overall acceptability of the dragon fruit based RTS was least (4) at $80 \%$ dragon fruit juice and $4 \%$ sugar syrup with $0 \%$ grape juice. Whereas, RTS having $80 \%$ dragon fruit juice, $5 \%$ grape juice and $6 \%$ sugar syrup was highly preferred (score $=9$ ) by the panel members. It was also revealed from the statistical analysis that concentration of dragon fruit juice $(P<0.01)$ and grape juice $(P<0.1)$ significantly affected the acceptability of the RTS (Fig. 7). The value of determination coefficient $\mathrm{R}^{2}$ was 0.93 . The following equation depicts the mathematical relationship between OA and process variables:

Overall acceptability $=7-0.8 \mathrm{X}_{1}-0.25 \mathrm{X}_{2}+0.50 \mathrm{X}_{1} \mathrm{X}_{2}$ $-0.50 \mathrm{X}_{2} \mathrm{X}_{3}-0.38 \mathrm{X}_{1}^{2}+0.38 \mathrm{X}_{2}^{2}$

Optimization of process variables: Numerical optimization was carried out using Design expert 9.0 by setting up goals for each independent and dependent parameter. The three variables were kept in range, $\mathrm{pH}$ is target to 4.90 , TSS $\left(12-15^{\circ} \mathrm{Brix}\right)$ and TA $(0.2-0.25 \%)$ were kept in range, AA (8.53-12.10), a* (11.49-20.52), TPC (15.9-46.2), taste (5-9), colour (4-9), flavour (69), OA (6-9) were maximized and $L^{*}(5.69-16.20)$ and b* (0.17-2.98) were minimized, respectively. About 32 solutions were obtained and the solution with maximum desirability of 0.85 was selected as the optimum solution. The optimum condition obtained was dragon fruit $(70 \%)$, grape juice $(5 \%)$ and sugar syrup (3\%), respectively. Experiments were conducted on these optimum conditions to validate this solution and the results were presented in Table 3 .

\section{Conclusion}

The effort was undertaken to prepare dragon fruit juice based ready to serve the beverage. Models ( $\mathrm{pH}$, TSS, titratable acidity, ascorbic acid content, colour, total phenol content, sensory evaluation) were found to be statistically valid and provided adequate information regarding the behaviour of the responses upon variation in concentration of dragon fruit juice, grape juice and sugar syrup. The optimum condition for dragon fruit juice based RTS was found to be $70 \%$ dragon fruit juice, $5 \%$ grape juice, $3 \%$ sugar syrup with remaining percentage of pomegranate juice $(22 \%)$. The respective values of responses are, $\mathrm{pH}(4.67 \pm 0.2)$, TSS $(11.90 \pm 0.98)$, acidity $(0.22 \pm 0.03)$, ascorbic acid content $(8.37 \pm 1.84), \mathrm{L}^{*}(7.74 \pm 0.87), \mathrm{a}^{*}(19.29 \pm 1.36)$, $b^{*}(1.86 \pm 0.6)$, TPC $(43.80 \pm 5.07 \mathrm{mg} / 100 \mathrm{~g})$ and overall acceptability $(8.50 \pm 0.74)$, respectively. The developed RTS can be used as micronutrient enriched health drinks.

\section{REFERENCES}

Anonymous (2017). http://blog.diabetv.com/dragon-fruit-and -diabetes-glucose-control AOAC (2000) 17th Ed., Official Methods of Analysis. International, Gaithersburg, MD, Method 942.15. 
AOAC (2000) 17th Ed., Official Methods of Analysis. International, Gaithersburg, MD, Method 967.21.

Bibwe, B., Mani, I., Kar, A. and Datta A. (2017).Optimization of Jackfruit seed starch soya protein isolate ratio and process variable for flaxseed oil encapsulation. Ind. J.Agril. Sci., 87(12):1657-1663

BIS: 6273. (1971) Part I and Part II. Guide for sensory evaluation of foods. Bureau of Indian Standards, New Delhi.

Chen Wu, L., Wen Hsu, H., Chen, Y.C., Chung Chiu, C., In Lin, Y., Annie Ho, J. (2006). Antioxidant and antiproliferative activities of red pitaya. Food Chem . 95:319-327.

Chuah, T.G., Ling, H.L., Chin, N.L., Choong, T.S.Y., Fakhru'l-Razi, A. (2008). Effects of temperatures on rheological behavior of dragon fruit (Hylocereus $s p$.) juice. Int J Food Eng. 4: 1-28.

Dailami, M.T.B. (2009). Production of dragon fruit powder using spray drying.

Davis (2007). Pitahaya (Dragon Fruit) Research and production in California UC small farm program specialty crops conference Davis, CA.

Harivaindaran, K.V., Rebecca, O.P.S., Chandran, S. (2008).Study of optimal temperature, $\mathrm{pH}$ and stability of dragon fruit (Hylocereuspolyrhizus) peel for use as potential natural colorant. Pakistan J Biol. Sci 11(18): 2259-2263.

Hoa, T.T., Clark, C.J., Waddell, B.C., Woolf, A.B. (2006). Postharvest quality of Dragon fruit (Hylocereusundatus) following disinfesting hot air treatments. Postharvest Bio Technol. 41(1): 62-69.
Kim, H., Choi, H.K., Moon, J.Y., Kim, Y.S., Mosaddik, A. (2011). Comparative antioxidant and antiproliferative activities of red and white pitayas and their correlation with flavonoid and polyphenol content. J Food Sci. 76: 38-45.

Le Bellec, F., Vaillant, F., Imbert, E. (2006). Pitahaya (Hylocereus spp.): A new fruit crop, a market with a future. Fruits. 61(4): 237-250.

Mahawar, M.K., Samuel, D.V.K., Sinha, J.P. (2016). Optimization of pea (Pisumsativum) seeds hydropriming by application of response surface methodology. Acta Physiol Plant. 38: 212.

Melendez-Martinez A.J, Vicario I.M., Heredia F.J. (2004). El color del zumo de naranja (II): aspectosfísicos: "Orange juice colour (II): physical aspects". Alimentación, Equipos y Tecnología 186: 103-106.

Siddhuraju P, Mohan P.S, Becker K. (2002) Studies on the antioxidant activity of Indian Laburnum (Cassia fistula L.): a preliminary assessment of crude extracts from stem bark, leaves, flowers and fruit pulp. Food Chem. 79:61-67.

Suguna, M., Wan-Nadiah, W.A., Liong, M.T., Bhat, R. (2011).Microbial safety of street vended and laboratory prepared dragon-fruit (pitaya) juices in Penang, Malaysia. Int Food Res J. 18(4): 1509-1513.

Wybraniec, S., Mizrahi, Y. (2002). Fruit flesh betacyanin pigments in Hylocereus cacti. J Agril Food Chem. 50: 6086-6089. 